\title{
Viral Diseases of Strawberry ${ }^{1}$
}

\author{
Catalina Moyer, Vance M. Whitaker, and Natalia A. Peres²
}

Viral diseases in strawberry are not easily detected because most single virus infections are symptomless on commercial cultivars. However, virus outbreaks have the potential for epidemics and economic losses. A mixed virus infection of strawberry mild yellow edge virus (SMYEV) and strawberry mottle virus (SMoV) was identified in several southeastern states during the 2012-13 season, resulting in millions of dollars in losses.

This updated version of a previous publication offers basic information on viral diseases of strawberry, with emphasis on viruses of potential threat to the strawberry industry in Florida. The primary target audience of this publication includes growers and industry personnel, Extension agents, and pathologists working with strawberry.

\section{Plant Viruses}

\section{Biology}

Viruses are submicroscopic parasites that are smaller than bacteria or fungi and not visible by light microscopy. Viruses have a variety of sizes and shapes (spherical, rod-shaped, isometric, etc.) and consist of DNA or RNA and protective proteins. Some viruses are among the most significant plant pathogens because they reduce plant vigor, yield, and market value, and can even cause death. Viruses multiply by inducing host cells to produce more virus particles. Plant viruses are obligate parasites that cannot be grown in artificial media and require a host plant for their survival and multiplication.

\section{Symptoms}

Virus-infected strawberry plants may be symptomless, or the symptoms may be confused with those caused by bacteria, viroids, insect feeding, herbicide damage, nutritional deficiencies, high temperatures (Figure 1), air pollutants, or genetic abnormalities (Converse 1987).

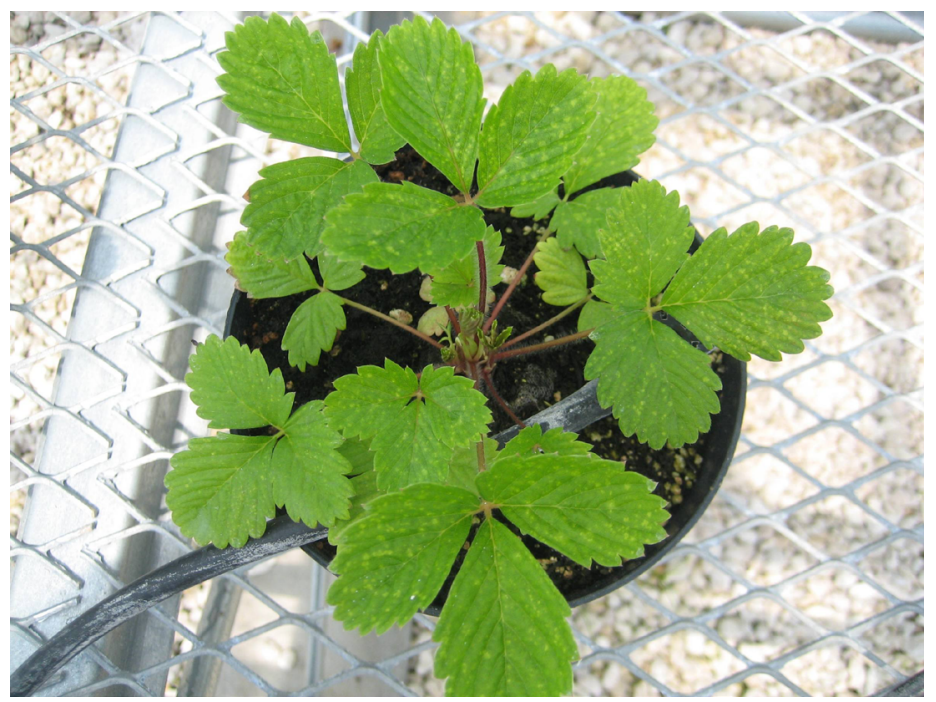

Figure 1. Symptoms caused by high temperature in F. vesca. Credits: Catalina Moyer, UF/IFAS

Virus symptoms may include mottle (uneven areas of light and dark yellowing) (Figure 2), ringspot (circular chlorotic spots), mosaic (mixed areas of mottled and normal tissue) (Figure 3), chlorosis or yellowing (pale or yellow areas) (Figure 4), malformation, leaf distortion, stunting (irregular growth, dwarfing, and loss of vigor), and reduced yield and fruit size.

1. This document is PP273, one of a series of the Plant Pathology Department, UF/IFAS Extension. Original publication date April 2010. Revised November 2021. Visit the EDIS website at https://edis.ifas.ufl.edu for the currently supported version of this publication.

2. Catalina Moyer, senior biological scientist; Vance M. Whitaker, associate professor, Horticultural Sciences Department; and Natalia A. Peres, professor, Plant Pathology Department; UF/IFAS Gulf Coast Research and Education Center, Wimauma, FL 33598.

The Institute of Food and Agricultural Sciences (IFAS) is an Equal Opportunity Institution authorized to provide research, educational information and other services

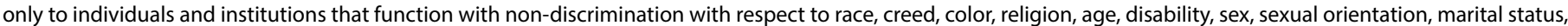

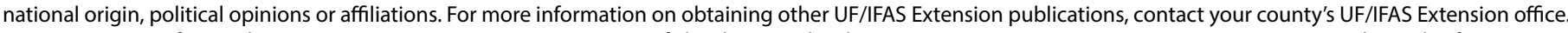
U.S. Department of Agriculture, UF/IFAS Extension Service, University of Florida, IFAS, Florida A \& M University Cooperative Extension Program, and Boards of County Commissioners Cooperating. Nick T. Place, dean for UF/IFAS Extension. 


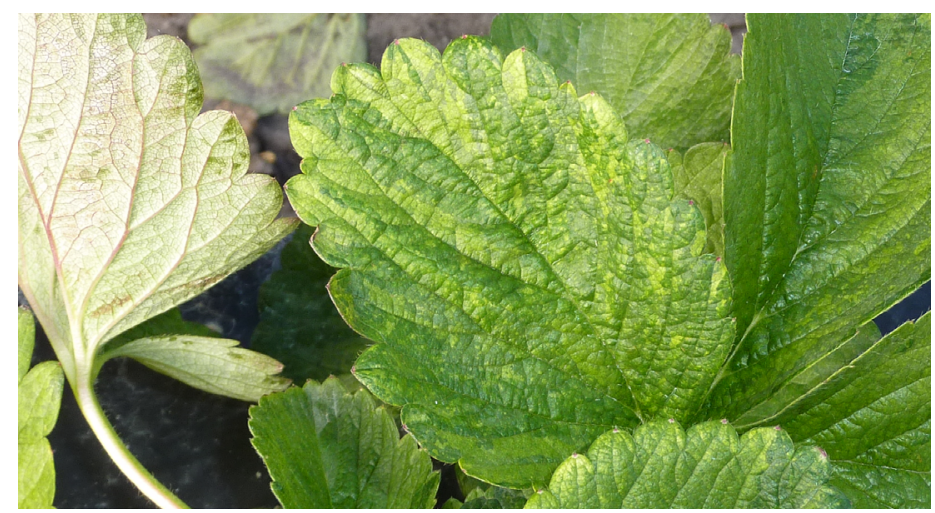

Figure 2. Strawberry leaf with mottle symptoms.

Credits: Catalina Moyer, UF/IFAS

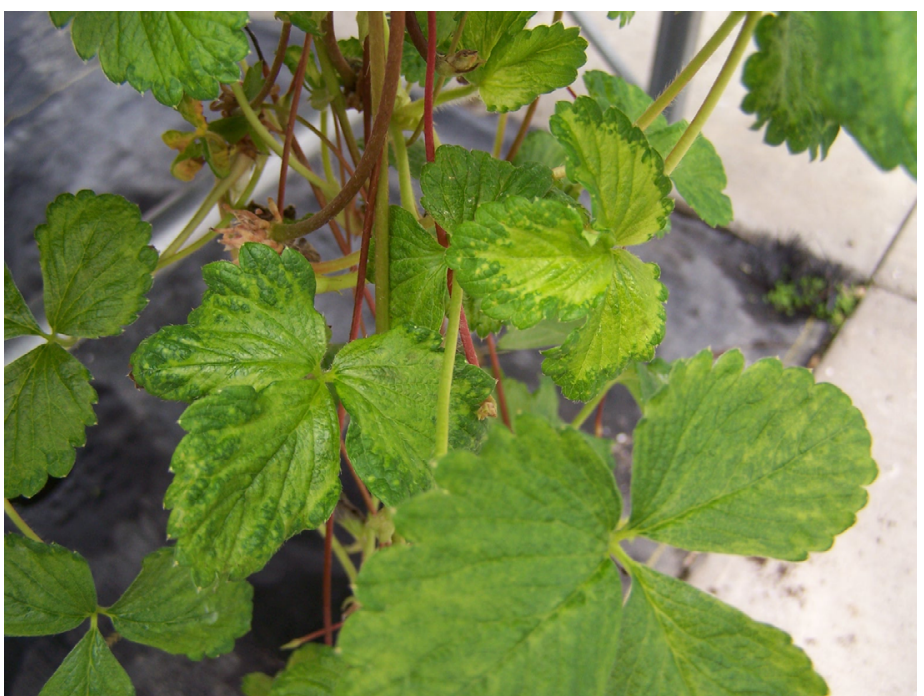

Figure 3. Strawberry plant showing a mosaic pattern on the leaves. Credits: Catalina Moyer, UF/IFAS

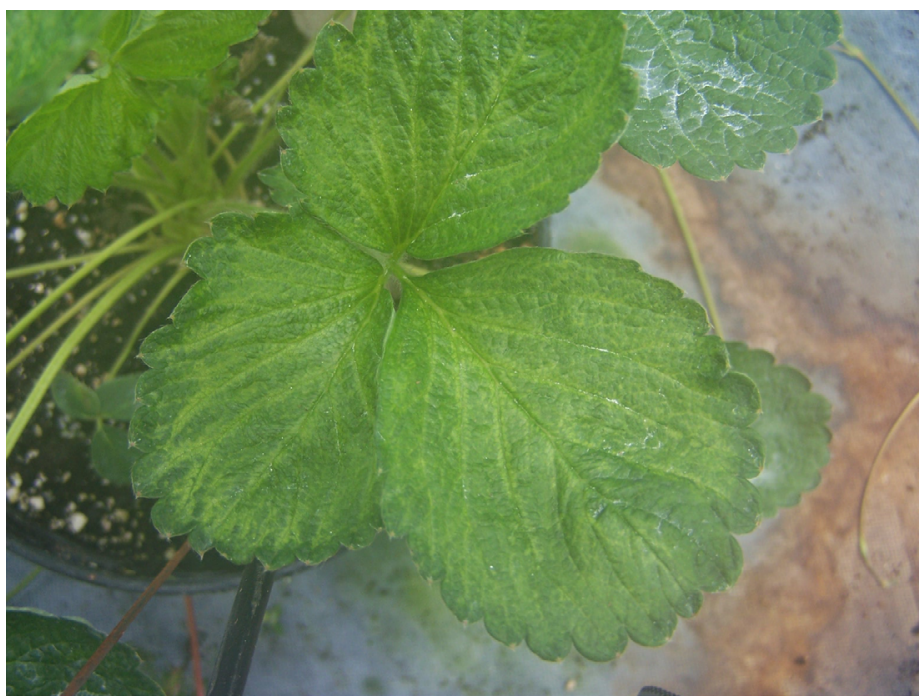

Figure 4. Strawberry leaf showing chlorosis.

Credits: Catalina Moyer, UF/IFAS

\section{Detection}

Detection and diagnosis of viral infections can be achieved by biological assays, such as graft or sap inoculation of species or cultivars that areespecially sensitive and show obvious symptoms (Martin 2004). If symptoms develop on these indicator plants, then the plant in question is positive for the virus (Figure 5). This technique can detect many viruses, although it will not necessarily diagnose a specific virus.

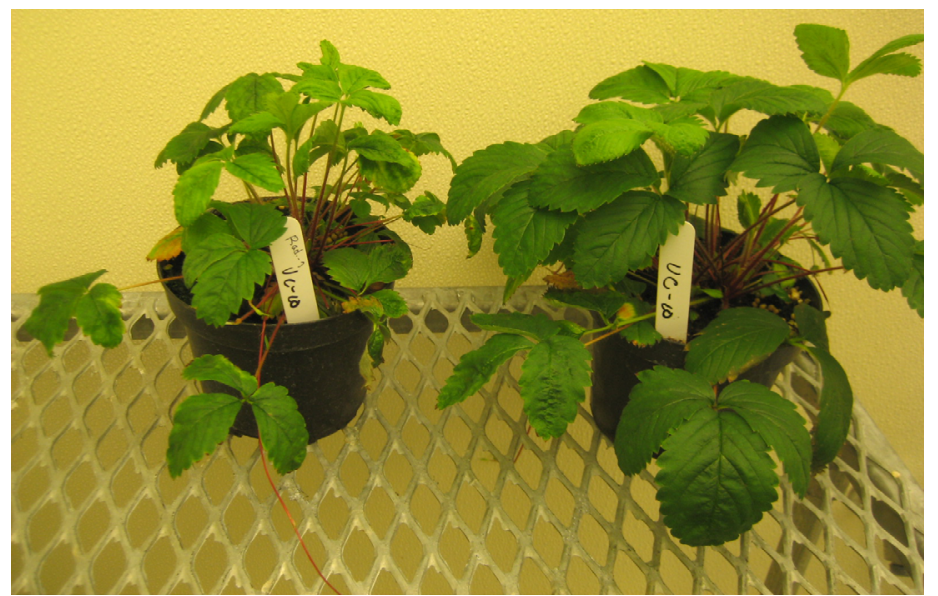

Figure 5. Fragaria virginiana indicator plants: right, healthy; left, leaf distortion and stunting symptoms after grafting with virus-infected tissue.

Credits: Catalina Moyer, UF/IFAS

Enzyme-linked immunosorbent assay (ELISA) is a serological test that detects the presence of a specific antigen (protein) in plant tissue. Leaf sap from virus-infected plants (containing the antigen) is mixed with the antibody for the specific virus in a microplate. If the antigens and antibody match, a color develops, indicating the presence of the virus in the sample (Figure 6). The wells in the microplate can be read visually as positive or negative or quantified with a colorimeter.

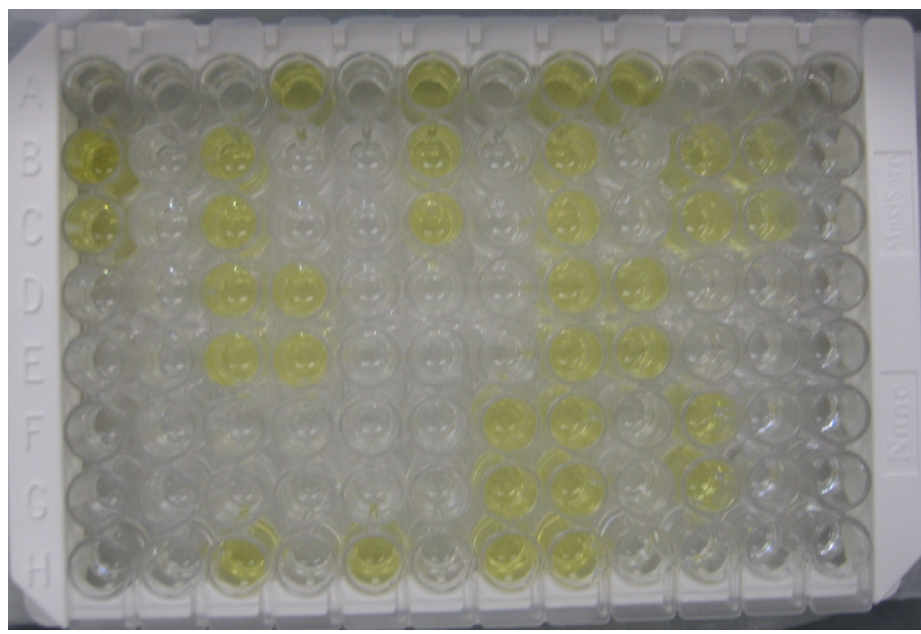

Figure 6. ELISA microplate showing colorimetric reaction of virusinfected samples.

Credits: Catalina Moyer, UF/IFAS

Nucleic acid analysis is another technique to confirm viral infection. Small amounts of DNA or RNA are amplified many times using polymerase chain reaction (PCR) and then detected with agarose gel electrophoresis or 
high-resolution melting analysis. Nucleic acid analyses are very useful in detecting organisms that cannot be cultured or that are present in very small amounts. However, detection of an organism does not necessarily indicate disease, because PCR does not discriminate between alive, dead, or infectious.

New technologies such as next-generation DNA sequencing (NGS) are now being used for the detection of known and novel viruses. NGS can provide very detailed information about the DNA or RNA molecules that make up viruses and other organisms. These technologies allow more accurate detection and identification of viruses on plants and insect vectors even when they are present in minuscule amounts, aka "low titer" (Barba et al. 2014; Villamor et al. 2019).

\section{Dissemination}

Plant viruses are disseminated through seed or pollen, vegetative propagation, or vectors (aphids, thrips, mites, whiteflies, leafhoppers, plant hoppers, beetles, and nematodes), or mechanically (Converse 1987). Dissemination of viruses is highly dependent on the presence of vectors and clonal plant propagation (Martin and Tzanetakis 2013).

\section{Management}

The most practical way to minimize the risk of infection in commercial strawberry fields is to use clean plant material (tissue-cultured and virus-tested) and to follow best management practices for insect and weed control (Biswas, Hossain, and Islam 2007; Martin and Tzanetakis 2006).

\section{Viruses in Strawberries}

Numerous viruses infect strawberry (Table 1), but the most prevalent in the United States in recent years are strawberry veinbanding virus (SVBV), strawberry crinkle virus (SCV) (Figure 7), strawberry mottle virus (SMoV), and strawberry mild yellow edgevirus (SMYEV), which are all transmitted by aphids, as well as strawberry pallidosis-associated virus (SPaV) and beet pseudo yellows virus (BPYV), transmitted by whiteflies.

Viral infections of commercially grown strawberries are rare because most viruses are eliminated during early stages of propagation. Cultivars go through a clean propagation program where meristem culture, heat treatment, and disease testing are conducted before plants are delivered to registered nurseries for mass propagation. However, strawberry fields may become infected with viruses that have hosts other than strawberry, such as bean, clover, tomato, and weed species, among others (Cupertino et al. 1984; Klose et al. 1996).

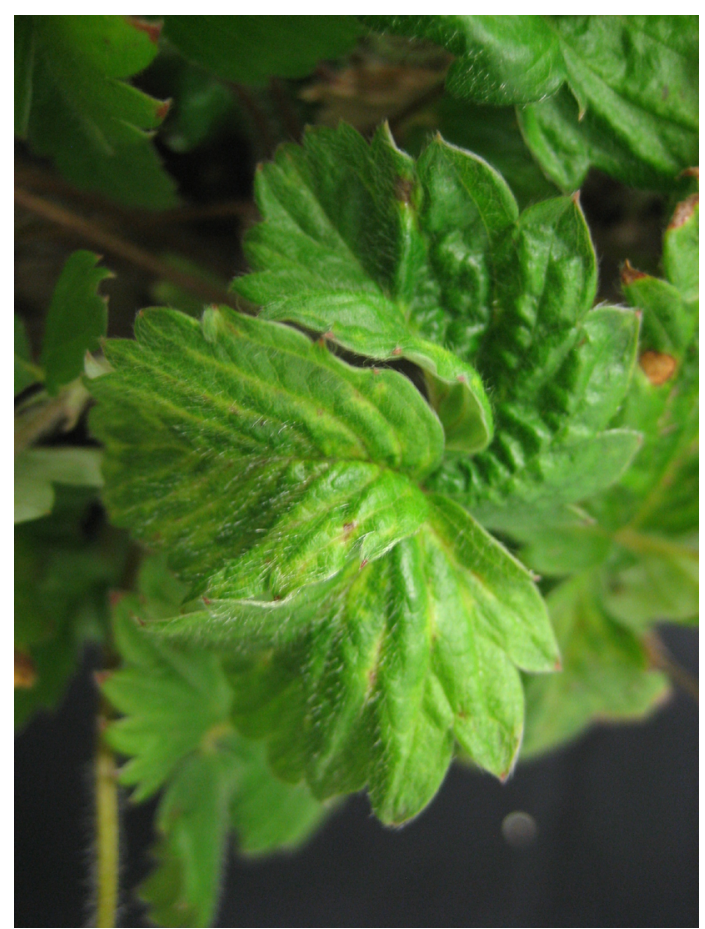

Figure 7. Close-up of a strawberry plant showing leaf crinkle virus symptoms.

Credits: Catalina Moyer, UF/IFAS

A single virus infection does not cause symptoms in most cultivars. However, viruses that seem harmless by themselves may become problematic in combination with others (Martin and Tzanetakis 2006). Plants with these mixed infections may develop more severe symptoms than those harboring a single viral pathogen.

In 2012, strawberry growers in the southeastern states experienced the results of a mixed virus infection. Plants that showed no symptoms in the nursery and appeared healthy after establishment in fruiting fields later became stunted, with yellowing/reddening of the leaves. The plants produced few and very small fruit and, in some cases, died (Figure 8). Samples from the different states were submitted for testing at USDA-ARS in Corvallis, OR, and two strawberry viruses were detected consistently: strawberry mild yellow edgevirus (SMYEV) and strawberry mottle virus $(\mathrm{SMoV})$. The infection was traced back to strawberry plants produced in Nova Scotia, Canada. Fortunately, the disease was not spread in the fruiting fields to plants from other nursery sources. However, the economic losses were estimated in the millions of dollars for the fruit growers and the nursery involved (Samtani et al. 2017).

Virus detection is an important step for disease management and throughout the plant propagation process. Negative results for diagnostic tests only indicate that plants are free of those viruses for which they have been tested. Therefore, plants that have tested negative should be called 
"virus-tested" and not "virus-free." Nonetheless, the term "virus-free" could potentially apply to plants tested using NGS with the caveat that detection of an unknown virus will require further evaluation to determine the biological effects and significance for each crop.

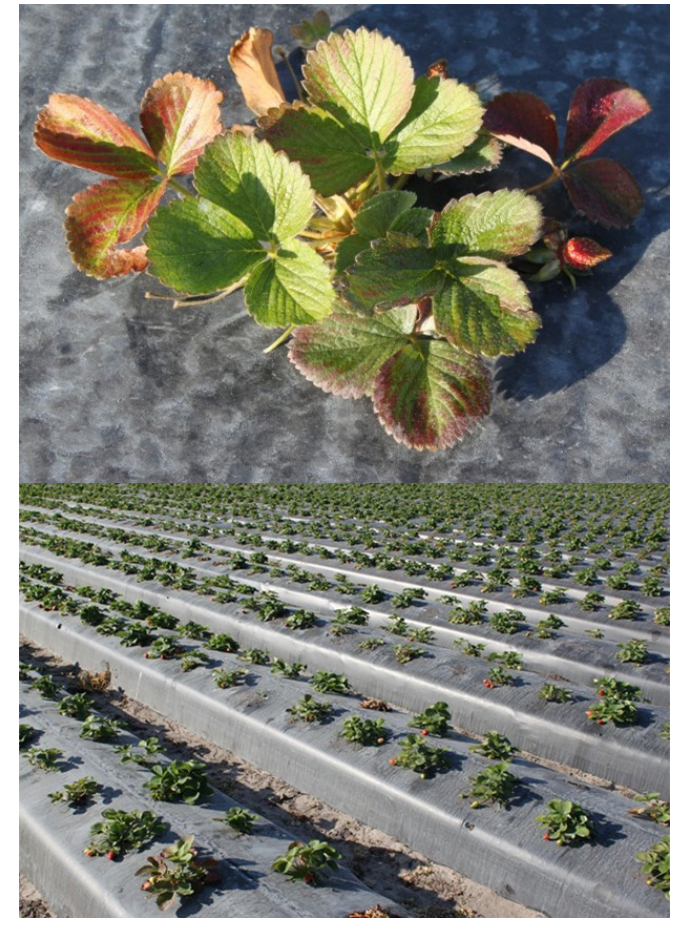

Figure 8. Left, leaf-reddening symptom associated with virus infections in 'Strawberry Festival'. Right, stunted plants in a field planted in October 2012 (photo taken on January 16, 2013). Credits: Dr. Natalia Peres, UF/IFAS

Registration and certification programs are in place to confirm the health of propagation material. However, it is not possible or practical to sample every plant in a field. Therefore, detection of viral infections will depend on the sampling method, and errors in both processes may result in an outbreak of certified material.

The following viral diseases haveoccurred in strawberry plants grown in Florida and are considered high-risk strawberry diseases in the region.

\section{Strawberry Mottle}

$\mathrm{SMoV}$ is the most common virus of strawberries, and all Fragaria species are susceptible even though no symptoms are visible oncommercial cultivars. SMoV is found more often in mixed infections with other viruses causing significant damage in strawberries.

Dissemination occurs by aphids (Chaetosiphon spp. and the melon aphid, Aphis gossypii) in a semipersistent manner in which the virus is acquired and transmitted in a few minutes (Martin and Tzanetakis 2006). The aphids probe infected plants and then move to healthy ones. If most plants in the field are healthy, the rate of infection will be reduced, because the virus will only reside in aphid stylets for a few hours. Moreover, this virus is heat-sensitive and therefore easily eliminated with heat treatment (Maas 1998).

$\mathrm{SMoV}$ can be detected by transmission to indicator plants, but because $\mathrm{SMoV}$ is often mixed with other viruses, definite identification is better achieved with PCR.

In 2014-2015, viral infection sources in strawberry fields of Quebec, Canada were surveyed. SMoV alone or in combination with other viruses was the most predominant virus found, and the greatest source of infection was virus-infected vectors followed by alternate plant hosts near strawberry fields (Bonneau et al. 2019).The incidence of $\mathrm{SMoV}$ is proportional to the aphid population in the field, and thus pest management practices are likely to reduce infection rates.

\section{Strawberry Mild Yellow Edge}

This disease is part of the yellows complex, one of the major diseases of strawberries, caused by a mixture of SMYEV with SMoV or SCV or both (Maas 1998). SMYEV is a very common virus in cultivated strawberries around the world; however, there is limited information about effects on strawberry in single infections. Torrico et al. (2018) found that plants with a single infection of SMYEV had reduced yields of $28 \%-63 \%$ even though plants were asymptomatic. However, they suggest that infection during the first fruit cycle may not influence productivity.

\section{SMYEV is transmitted by some aphids (Chaetosiphon} genus) in a persistent circulative manner; that is, the aphid needs to feed on an infected plant for hours or days to acquire the virus, which then spreads throughout the aphid and remains inside the aphid for life. Nonetheless, successful transmission depends on the virus strain and on the efficiency of the vector (Converse 1987).

Virus detection can be achieved by grafting sensitive indicator hosts. However, specific identification of SMYEV can be faster and more practical using RT-PCR and or ELISA (Martin and Tzanetakis 2006). This virus can survive heat treatment, and virus titer is higher during high summer temperatures. Therefore, diagnosis can be affected by the time of sampling (Converse 1987; Torrico et al. 2018). 


\section{Strawberry Decline or Pallidosis-Related Decline}

This disease is caused by infection by multiple viruses from different sources. Symptoms vary among strawberry species and cultivars: infected plants may exhibit chlorosis, purple coloration of leaves, stunting, and dieback (Martin and Tzanetakis 2013; Dara 2015). The virus identified in diseased plants were BPYV, SPaV, SMYEV, SMoV, and a newly identified virus, strawberry polerovirus 1 (SPV1) (Tzanetakis et al. 2006; Xiang 2015).

Strawberry decline was considered rare, but in 2000 and 2003, it affected the strawberry industry on the West Coast from Canada to Southern California. Then, in 2012, a new outbreak occurred on the West Coast causing significant economic losses. A YouTube video made by the University of California Cooperative Extension shows an overview of SD (http://www.youtube.com/watch?v=m1YRRE_PY8s).

\section{Strawberry Necrotic Shock}

For many years, strawberry necrotic shock disease was thought to be caused by a strain of tobacco streak virus (TSV). Tzanetakis, Mackey, and Martin (2004) found that strawberry necrotic shock disease is caused by a different virus and not by a strain of TSV. The name "strawberry necrotic shock virus" (SNSV) was then suggested for this virus instead of TSV.

SNSV was detected in Florida at the end of the 2008-2009 strawberry season in research fields at the UF/IFAS Gulf Coast Research and Education Center. However, yields were not noticeably different from those in previous years. Thus, it was assumed these were new infections of SNSV that were transmitted in Florida; however, the hypotheses that the plants were infected in the nurseries could not be dismissed because plants were not tested early in the season.

During the 2009-2010 strawberry season, leaf samples were collected from multiple cultivars and different nursery sources at three times during the season. SNSV was confirmed in 'Florida Radiance' from all nursery sources, 'Florida Elyana' from one source, and 'Strawberry Festival' from two sources. Despite the presence of SNSV in 'Florida Radiance' since the beginning of the season, yields did not seem to be affected, and SNSV was not detected in other cultivars planted nearby. This indicated that transmission and infection by SNSV did not progress rapidly in strawberry fields. However, it is possible that the colderthan-normal temperatures during the 2009-10 strawberry season prevented more rapid spread of SNSV.

\section{Conclusions}

In general, infection by a single strawberry virus does not significantly affect strawberry growth and yield. However, mixed infections by multiple viruses have the potential to cause serious losses. For this reason, it is important to minimize the risk of virus infections by using plants that have been properly propagated using meristem culture, heat treatment, and virus testing, and by ensuring best pest management practices in the field to minimize incursion of new viruses.

\section{References}

Barba, M., H. Czosnek, and A. Hadidi. 2014. "Historical Perspective, Development and Applications of NextGeneration Sequencing in Plant Virology." Viruses 6 (1): 106-136.https://doi.org/10.3390/v6010106

Biswas, M. K., M. Hossain, and R. Islam. 2007. "Virus Free Plantlets Production of Strawberry through Meristem Culture." World J. Agric. Sci. 3 (6): 757-763.

Bonneau, P., R. Hogue, S. Tellier, and V. Fournier. 2019. "Evaluation of Various Sources of Viral Infection in Strawberry of Quebec, Canada." Journal of Economic Entomology 112 (6): 2577-2583. https://doi.org/10.1093/ jee/toz205

Converse, R. H. 1987. "Virus and Viruslike Diseases of Fragaria (Strawberry).” In Virus Diseases of Small Fruits, 1-100. U.S. Dep. Agric. Res. Serv. Agric. Handb. No. 631.

Cupertino, F. P., R. G. Grogan, L. J. Petersen, and K. A. Kimble. 1984. “Tobacco Streak Virus Infection of Tomato and Some Natural Weed Hosts in California." Plant Dis. 68:331-333. https://doi.org/10.1094/PD-68-331

Dara, S. K. 2015. "Virus Decline of Strawberry in California and the Role of Insect Vectors and Associated Viruses." Plant Health Progress 16 (4): 211-215. https://doi. org/10.1094/PHP-MR-15-0023

Diekmann, M., E. A. Frison, and T. Putter (eds). 1994. FAO/ IPGRI Technical Guidelines for the Safe Movement of Small Fruit Germplasm. Rome: Food and Agriculture Organization of the United Nations, International Plant Genetic Resources Institute.

Frazier, N. W., P. S. Jorgensen, H. E. Thomas, and H. A. Johnson, Jr. 1962. "Necrotic Shock: A Virus Disease of Strawberries." Plant Dis. Rep. 46:547-550. 
Klose, M. J., R. Sdoodee, D. S. Teakle, J. R. Milne, R. S. Greber, and G. H. Walter. 1996.“Transmission of Three Strains of Tobacco Streak Ilarvirusby Different Thrips Species Using Virus-Infected Pollen.” Phytopathology 144 (6): 281-284. https://doi.org/10.1111/j.1439-0434.1996. tb01530.x

Maas, J. L. 1998. Compendium of Strawberry Diseases. Second Edition. St. Paul, MN: APS Press. https://doi. org/10.1094/9780890546178

Martin, R. R. 2004. "Recommended Procedures for Detection of Viruses of Small Fruit Crops." Acta Hortic. 656:222-234.

Martin, R. R., and I. E. Tzanetakis. 2006. "Characterization and Recent Advances in Detection of Strawberry Viruses." Plant Dis. 90 (4): 384-396. https://doi.org/10.1094/ PD-90-0384

Martin, R. R., and I. E. Tzanetakis. 2013. "High Risk Strawberry Viruses by Region in the United States and Canada: Implications for Certification, Nurseries, and Fruit Production." Plant Dis. 97 (10): 1358-62. https://doi. org/10.1094/PDIS-09-12-0842-RE

Mullin, R. H., S. H. Smith, N. W. Frazier, D. E. Schlegel, and S. R. McCall. 1974. "Meristem Culture Frees Strawberries of Mild Yellow Edge, Pallidosis, and Mottle Diseases."

Phytopathology 64:1425-1429. https://doi.org/10.1094/

Phyto-64-1425

Samtani, J. B., C. S. Johnson, R. Flanagan III, K. Starke, B. Poling, and R. R. Martin. 2017. "Mixed Infection of Strawberry Mottle Virus and Strawberry Mild Yellow Edge Virus in the Southeastern United States." Virginia Cooperative Extension, Virginia Tech. VT/0917/HORT-268P. http://hdl. handle.net/10919/81693

Torrico, A. K., S. M. Salazar, D. S. Kirschbaum, and V. C. Conci. 2018. "Yield Losses of Asymptomatic Strawberry Plants Infected with Strawberry mild yellow edge virus." European Journal of Plant Pathology 150:983-990. https:// doi.org/10.1007/s10658-017-1337-z

Tzanetakis, I. E., I. C. Mackey, and R. R. Martin. 2004. "Strawberry Necrotic Shock Virus Is a Distinct Virus and Not a Strain of Tobacco streak virus." Arch. Virol. 149:2001-2011. https://doi.org/10.1007/s00705-004-0330-y
Tzanetakis, I. E., W. M. Wintermantel, A. A. Cortez, J. E. Barnes, S. M. Barrett, M. P. Bolda, and R. R. Martin. 2006. "Epidemiology of Strawberry Pallidosis Associated Virus and Occurrence of Pallidosis Disease in North America." Plant Dis. 90 (10): 1343-1346. https://doi.org/10.1094/ PD-90-1343

Villamor, D. E. V., T. Ho, M. Al Rwahnih, R. R. Martin, and I. E. Tzanetakis. 2019. "High Throughput Sequencing for Plant Virus Detection and Discovery." Phytopathology 109 (5): 716-725. https://doi.org/10.1094/ PHYTO-07-18-0257-RVW

Xiang, Y., M. Bernardy, B. Bhagwat, P. A. Wiersma, R. De Young, and M. Bouthillier. 2015. "The Complete Genome Sequence of a New Polerovirusin Strawberry Plants from Eastern Canada Showing Strawberry Decline Symptoms." Archives of Virology 160:553-556. https://doi.org/10.1007/ s00705-014-2267-0 

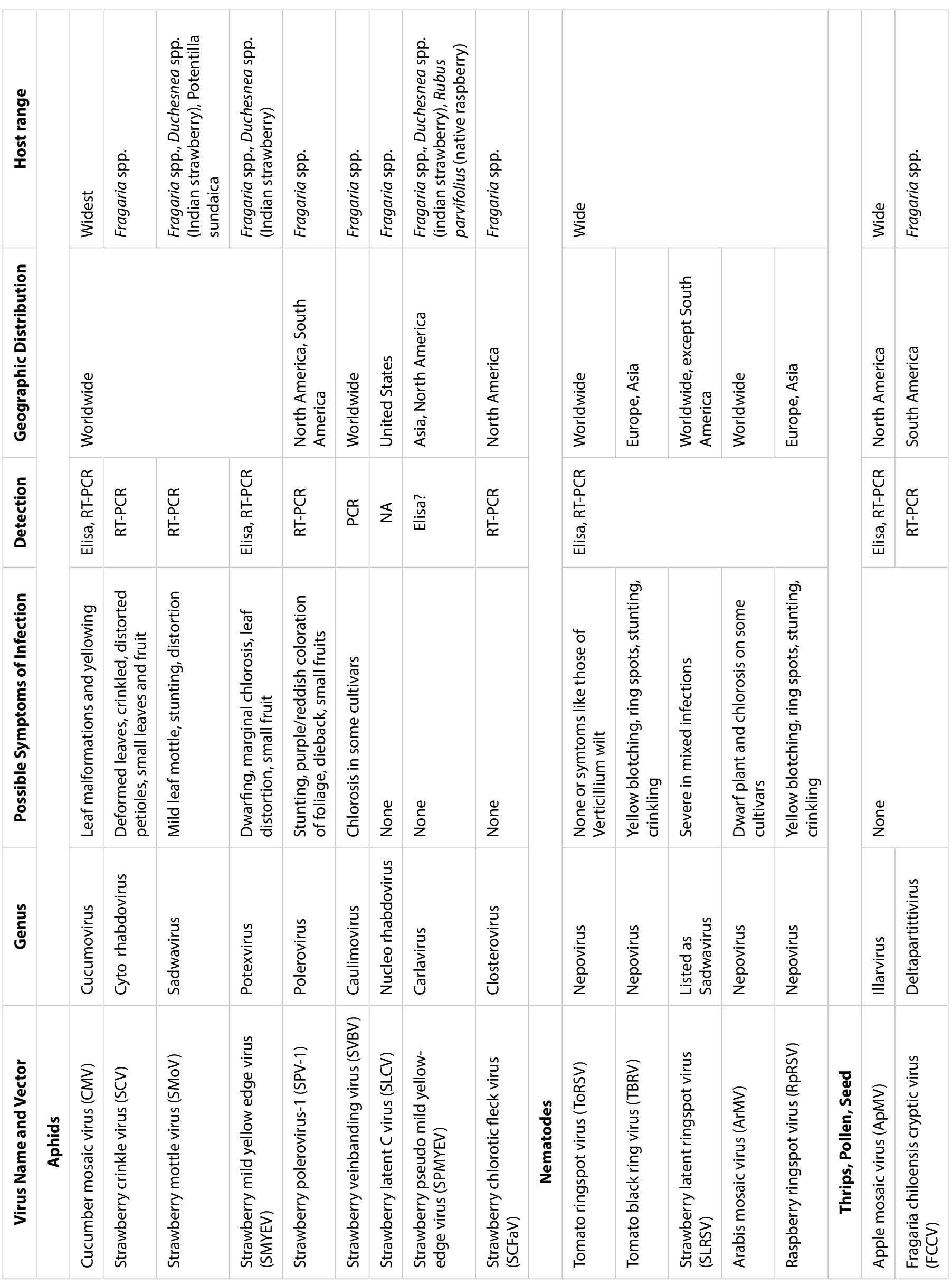


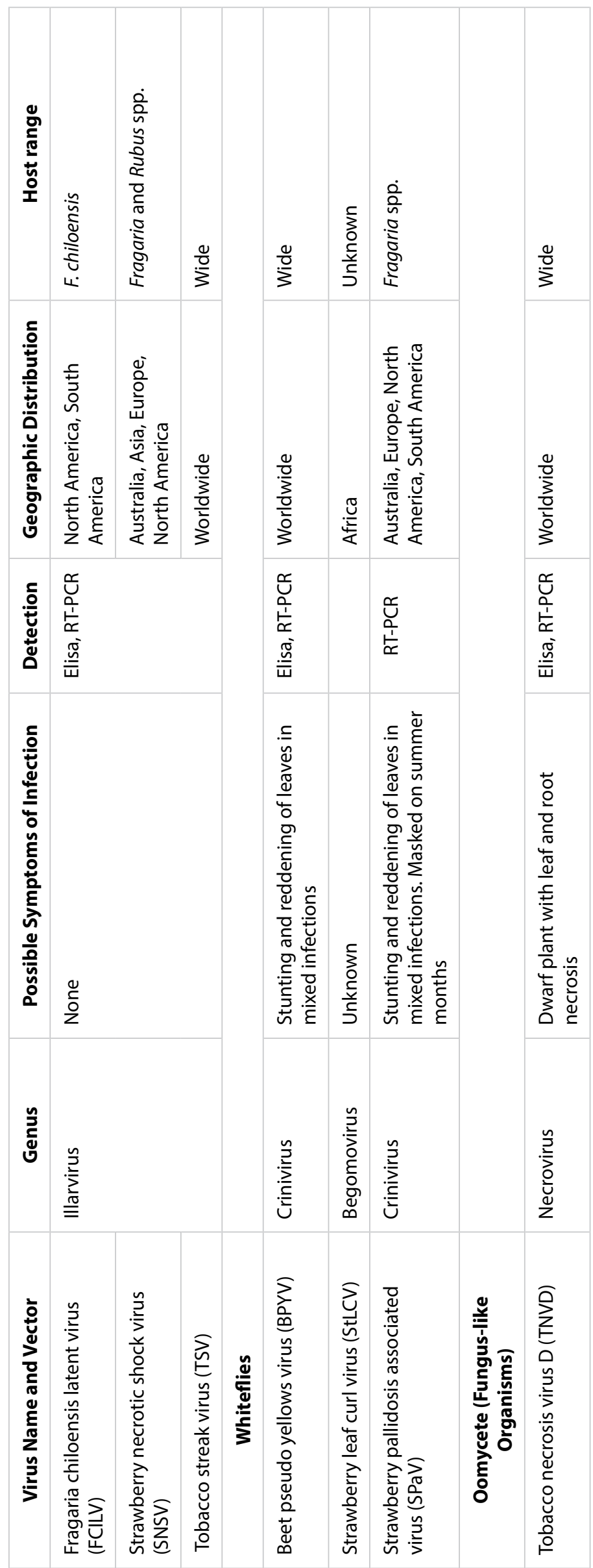

